\title{
'The Empire of the Status Quo': To the Second Degree or a Reply to Louky Bersianik
}

\author{
Barbara Godard
}

\begin{abstract}
'L'Empire du statu quo': au deuxième degré
En réplique au texte de Louky Bersianik, 'L'Empire du statu quo,' paru dans Tessera No.4, l'auteure propose une lecture 'au deuxième degré' $d u$ Déclin de l'empire américain. Alors que Bersianik se penche sur l'énoncé des personnages pour dénoncer le film comme misogyne, Godard examine l'instance d'énonciation dans son réseau intertextuel pour conclure qu'Arcand déstabilise les images stéréotypées des femmes. Parle même jeu d'ironie et de parodiequi expose un écart entre leurs paroles et leurs gestes, il met en question les images également stéréotypées des hommes. Cependant, comme nous le montre la vive réaction de Bersianik, le film produit un regard masculin. La colère de Bersianik nous permet d'apercevoir un regard féministe qui ne figure que dans la résistance.
\end{abstract}

Surely the most successful Quebec film ever, Denys Arcand's The Decline of the American Empire, with its laurels from Cannes still green, opened in Montreal to a salvo from Louky Bersianik accusing it of enshrining the 'clichés' of 'ordinary everyday sexism,' 'male fantasies'; in short, of forming an ideological treatise in support of 'patriarchal power.' This feminist critique attacks Arcand's ethical responsibility as a historian: aware of the impact of feminism on contemporary society, he nonetheless fails to reveal any trace of feminist consciousness whatsoever. It is a film about sexual jokes, Bersianik concludes, not about history: 'Le véritable propos de ce film n'est pas l'histoire comme on pourrait le croire, mais les rapports entre les hommes et les femmes. ${ }^{1}$

History is an ethical touchstone for Bersianik. Re-membering is the primordial activity of futurologues and those who would effect social 
change, as Bersianik has demonstrated in her Utopian fictions, The Euguelionne and Piquenique sur l'Acropole. The debate Bersianik engages with what she perceives to be the thesis of the film, 'historically, the accession of women to power marks the beginning of the decline of civilizations' (my translation), begins with issues of historiography but, as happens in the film, quickly turns to an enumeration of the evidence to support her reading of the images of the victory of masculine macho power over feminine intelligence reduced to the 'power of the victim.' Bersianik's article has in turn become almost as celebrated as the film, resulting in an animated debate in the pages of Le Devoir - readers writing to express delight that their uneasiness with the film had been named, quibbling over details of interpretation, or asking for rewrites of the film 'dedicated to love and laughter' - and in the academy, where feminist theory groups have analyzed her critique.

In the process, a qualifying voice has emerged, best articulated by Professor Anne Legaré who, seizing on the film's poor formulation of, and the superficiality of, the historical thesis in Dominique's book that when individuals seek personal happiness rather than the collective good, empires go into decline-suggests that Bersianik's reading of the film shows little confidence in the Quebec audience's interpretive skills. The audience directs its laughter at itself, Legaré maintains, because it has attained critical distance from the film and can recognize its limited vision: 'Il faut prêter au public québécois peu de subtilité pour croire qu'il prenne au premier degré tout ce qui lui est montré dans ce film....' ${ }^{2}$ The magic is in the image and not in the subject matter. Moreover, Bersianik is abstracting the ideology from the film in an inductive operation grounded in a static idea of the interpretive process of the spectator.

Le film dépeint bien des fantasmes masculins choquants et, en cela, nous rappelle un univers bien détestable. Cependant, sil'on ne fait que se placer au niveau où une analyse sévère se substitue à un réel détestable, on n'est guère plus avancé. C'est en effet, une induction un peu simpliste qui voudrait que les représentations symboliques ou fantasmatiques des rapports hommes/femmes, qui traversent ce film, s'impriment directement sur la conscience des spectateurs, comme si celle-ci était une plaque réfléchissante. Les spectateurs ont une vie, vivent 
des conflits et sont interpellés par de multiples discours. Les processus concrets, qui agitent les expériences, sont le terreau des représentations. L'oublier, $c^{\prime}$ est faire du spectacle une piéce figée, analysable en elle-même et pour elle-même.

A dialectic model of viewer/text relations is called for. Legaré points out, though doesn't carry out, the need for a thorough intertextual analysis of The Decline of the American Empire, a reading of the text, not just of the story and/or discourse abstracted from the text and its relationship to other texts. A reading in the second degree! ${ }^{3}$

In this intertextual reading, I have the advantage of several viewings of the film, many rewritings in hand, its published script, the printed debate in Le Devoir, as well as a year's informal discussions with friends and colleagues. In all this material, it is interesting first of all to examine the gap between Bersianik's formulation of the film's thesis and that of Legaré. Bersianik focusses on the question of sexual difference, highlighting the equation between the women's movement and the decline of civic power as formulated by Arcand's characters. Legaré quotes the thesis of Dominique's book and emphasizes contemporary circuses or personal pleasure. The difference between the two reading of the film's thesis may lie in the feminist theory Bersianik upholds, that the personal is political. But it may also be located in her confounding of story and discourse. ${ }^{4}$

This slippage from the activity of enunciating to the content of the utterance is abetted by the male characters in the film, especially Rémy who waves the red flag of sexist comments for critical feminists. In an interview with Diane which is the second scene in the film, Dominique states her thesis in terms of the quest for 'bonheur personnel. ${ }^{5}$ In the following scene, Rémy comments to Pierre that it is strange Dominique doesn't mention women. In his reply, Pierre articulates Rémy's reading of the hypothesis in its negative inversion in order to question it: 'Je ne suis pas sûr qu' elle ait eu envie de poserl'équation du pouvoir féminin et de la décomposition sociale' (p.16). Clearly, this denial of the link between women's empowerment and social disintegration is not effective, since Bersianik latches on to this and blows it up into the thesis of the whole film instead of exposing it as an indication of the blatant sexism of this particular character. For the spectator, the difference between written text and film, lies in the possibility provided to the reader of making fine distinctions in characterization in 
reading. Reading is inevitably re-reading, hence exploration of 'the critical difference. 6

While this indicates the care one must take in viewing Arcand's films in order to grasp his subtle ironies, it does nothing to invalidate Bersianik's thesis that the film deploys current stereotypes of submissive femininity. Everyone agrees on the conventionality of the images of the women. The question is, what does the film do with these clichés? Are they deployed to maintain the status quo by providing the pleasure of identification to the spectator, suturing the spectator to the subject position assuring the perpetuation of dominant ideology? Or are these clichés problematized, put into question by the film text? Some critics suggest this is the case: 'Partant de ce qui pourrait n'être que clichés, Denys Arcand, avec un ironie souveraine, cisèle amoureusement ses personnages et nous entraîne avec eux sur un tapis roulant. ${ }^{7}$

Arcand's irony in The Decline of the American Empire is complex and cuts in many directions. Not the least of the interpretive dilemmas posed is that occasioned by parody and clichés which are dependent on the spectator's recognition of them to activate the recontextualization which would lead to repetition with $a$ difference. Cliché and parody as modes of intertextuality are always double voiced, both sing alongs and countersongs, repetitions which validate what they repeat by the very fact of repeating and differential readings of them through the fact of recontextualizing them. Added to this complexity is the tension between Arcand's initial intention to make a film about the relationships between men and women ${ }^{8}$ and the characteristic trait of his films to engage in political debate on the Quebec collective identity. That these two versions of the political remain in tension is the ultimate proof of Arcand's failure to embrace feminism, whose slogan of the seventies - the personal is political - he travesties in the words, moreover, of a woman historian. This, in a film, which is intertextually positioned within the text of Quebec historiography!

Before exploring this, however, let us return to the question of clichés. The spiral of ironies mounts with each stereotype and inversion, for inversion is the most frequent ironic technique employed by Arcand as he turns his female characters into masochistic victims or honourary males. A pitiful gallery of portraits they make: Louise, the naïve, dependent housewife who spends all her time keeping her 
body slim to retain a wandering husband, a body which seems to give her little pleasure for all her fatigue; Danielle, the 'working girl,' a geisha girl version of feminine subservience, who masturbates her teacher in a soft porn inversion of power. Then there is Diane, the woman on her own, oppressed by the economic order as a teaching assistant with no hope of promotion within the system, whoyet extols the 'power of the victim' in her sexual relationship with a sadist.

Dominique, the one woman who seems to have achieved a certain independence as published author and head of the history department, is shown to have done so at the expense of personal relationships. Her bed is generally empty, or occupied by her colleagues who use this sexual contact as a means of subverting her authority as a historian, abandoning her precipitously after sex and failing to take her work seriously, except for the young graduatestudent Alain who, like Danielle, quickly learns the way to power passes through the bedroom. In this, Dominique is caught up in a complex game of mirrors, not a projection of masculine fantasies like the other three women but an inverted reflection of their lives. A token male, she does not have it all either.

What social revolution has the film posited for the 'new woman'? Certainly it has not dreamed a new order in which women would no longer be oppressed and feminine values would be honoured. Women's liberation is travestied in this film where liberation is restricted to the so-called sexual revolution, the free love much vaunted in the sixties but which feminists, more recently, have been proving to have been a liberation for men only. Moreover, women's 'liberated' sexuality according to this film, mirrors male sexuality in its concern with measurement and dismemberment, with giving marks to men's performance - 'il sait que tu lui donnes une note, là ... tu sais, du genre ... guide ... gastronomique,' (p. 101) or of a tourists' guidebook (p. 102) - and the size of the penis (p.99). This locker room discourse on the fragmented male body is modelled on the masculine norm of the female body cut into pieces and reified, unlike the rare, artistic depictions of the male body in the feminine imaginary where the nude body is not offered as a commodity for the male gaze but lovingly held by a female (as in the 'Sphinx Amalburga' by Leonor Fini, for example). These locker room scenes are the frequent butt of the anger of feminist spectators who object to the lack of verisimilitude in 
the coldness and detachment of the women's speech about sex. Men counter with a story that Arcand asked the women to write the dialogue themselves, a rumour which would seem to find support in the list of credits for the film where the name of feminist sociologist, Louise Vandelac, figures prominently. That she did prelimary research for Arcand is true, Vandelac has publicly stated. She saw no final script, however, nor did she agree to have her name appear on the screen in approval of the final text, as she angrily denounces in an effort to clear her name. Her ideas have been used as the negative and invisible point from which Arcand has fabricated his own vision of things. 9

That this view confirms Andrea Dworkin's thesis that 'normal' intercourse is both the model and the enforcer of male supremacy, that the major instrument of patriarchy is male sexuality which requires female subservience as sexual objects with all the accompanying self-deception, submission, pain and powerlessness that is unfolded before us in this film, ${ }^{10}$ is evidence of the extent to which this film produces a subject position for the male spectator. This is the discourse of historical masturbation as Luce Irigaray has outlined it, a 'hom(m)o-sexual monopoly' functioning on the mode of semblance:

In this new matrix of History, in which man begets man as his own likeness, wives, daughters, and sisters have value only in that they serve as the possibility of, and potential benefit in, relations among men. The use of and traffic in women subtend and uphold the reign of masculine hom(m)osexuality, even while they maintain that hom(m)o-sexuality in speculations, mirror games, identifications and more or less rivalrous appropriations, which defer its real practice. Reigning everywhere, although prohibited in practice, hom(m)o-sexuality is played out through the bodies of women, matter, or sign, and heterosexuality has up to now been just an alibi for the smooth workings of man's relations with himself, of relations among men. ${ }^{14}$

Despite this dominance of the male gaze, there are two momentary breaks where it is disturbed and blurred. The first of these occurs around the dinner table when, as the group are reminiscing about their student days, Diane replies to Rémy's comment on the frivolity 
of her students - women interested in learning German or the guitar, not in serious learning (p.112) - with an other historiography, one which would focus on something other than the history of power and the powerful. Moved by this embryonic formulation of what might become a feminist historiography, she continues with an outburst of anger about her own situation when, confined to the house with children, she learned more about Kelloggs than the Kellog-Briand pact, raised children while Rémy and Pierre went off to graduate school at Berkeley and Princeton, and is consequently only a part-time teacher at one-fifth their salary with no sabbaticals or pension (p.114). This interruption in the patriarchal discourse is smoothed over by whimsical banter about the Laotian chiefs whose names were perennial exam traps, Rémy's reply to her anger, which effectively silences and marginalizes her protest.

The other moment occurs in the final scene when Louise, eyes hidden behind dark glasses, comes downstairs after her sleepless night of truth and is drawn to the piano by Danielle to play a duet. As closure, this scene may be read in several ways, as evidence of female solidarity where the younger woman reaches out to bring Louise into a world in which she has her own expertise as a musician, a life independent of Rémy which the film has totally hidden from us until now, a world in which she may find a new raison d'être and no longer be submissive. On the other hand, this moment of complicity may take its place along with other morning encounters, the hug between Diane and Claude, the cooking of Alain which cements his liaison with Dominique and marks his accession to manhood on the model of Rémy and Pierre, as one more sign that the world continues to turn in its orbit. Plus ça change, plus.... Given the textual elision of the first interruption, I read this second with a cynical eye. Nothing much has disturbed the patriarchal order, though for a few seconds we have seen how the world might be viewed otherwise. The opening of this ambiguity, however, is an important element in the ironical game of mirrors played by Arcand in which the same is refracted through the speculations of the speculum in destabilizing irony.

While Bersianik's feminist critique has focussed attention exclusively on the images of women in Arcand's film, his male characters are equally stereotyped and crippled by the current sexual order. The major difference is, they emerge as winners in their ability to silence woman. The four men represent a variety of masculine postures every 
bit as depressingly familiar and conventional as the women in this gallery. Most immediately obvious is the stereotyping of Claude, the caricatural gay, excellent cook, and teased about this by the other men (p.74), who, as a free-floating signifier, is propelled by the irresistable force of his desire for cruising into the trap of what appears to be AIDS. 'Sij' étais capable, je draguerais tous les soirs. C'est effrayant commeje me sens quand je sors' (p.57). This he does, despite the knowledge that he might wind up with a knife in his back, like one of his friends. Frightful it is when the spectator sees the bloody urine in the toilet. Even more disturbing is the facile black and white ethical system operative in the film which labels sexual difference as immoral and to be punished and advances a conservative discourse on AIDS as an exclusively sexually transmitted disease, not as a universal malady of the blood stream. Claude shares with the women the limited power of the victim, a position signalled in the shared embrace with Diane on the morning following the dark night of the soul. However, he is also the most openly misogynist of the four. Ironically, in view of his own situation, he presents a view of the female belly as breeding ground of horrible contagious diseases (p.73). The male gaze is clearly in control of the production of the film's meaning since no comparable discourse on sexually transmitted diseases is presented by the women to expose the male body as a site of decay and decline.

Alain too moves in the sphere of powerlessness as a student so green that he has to have Dominique's help to break an egg for breakfast. Although he claims he is different from Rémy and Pierre in his relationships with women, the spectator sees he is not, since in the narrated world, like them, he is sleeping with Dominique, the department head. As well, he joins in the chorus of male commentary belittling Diane's evening course in history taught to women ('l'intégration primale,' p. 112) despite Danielle's glance of reprobation. Pierre confirms this parallel, moreover, by acknowledging that at Alain's age, he did not dream of possessing a new woman each night, and that Alain too will outgrow this as his career progresses and he contemplates both a full professorship and an ambitious publishing project (p.61). Sexual activity here is clearly a synonym for power.

Pierre and Rémy form another pair, connected by their apparent success, both professional and personal, Rémy especially in this latter domain, purportedly having 'fucked the city of Montreal.' The 'Red Cross,' he calls himself, the 'universal donor' (p.158). Pierre too 
presents himself as a 'ladies' man,' who has left his marriage because of the tension caused by phone calls from his many women to embark on a life of serial monogamy. His current woman is a student whose youth points up Pierre's failing potency. Contrasted here are Pierre's revision of Descartes after Wittgenstein - 'si j'aime je bande' (if I love, $I^{\prime} m$ erect, p.64) - and Danielle's remark when Pierre is too tired to make love - ' $T$ ' as une petites queu puis tu bandes mal!' (You've got a little cock that's not very hard!, p. 153). The gap between Pierre's fiction of desire and his action is made evident in the circumstances of their meeting in a brothel where he comes to be masturbated. His passivity is further reinforced in the inversion of roles where the prostitute, Danielle, an undergraduate student, talks at length to him about her interest in catastrophes and apocalyptic thinking while she masturbates him (pp. 140-2). The pathos of Pierre's situation is underlined by his earlier laughter at the great theorists of sexuality who frequented massage parlours (p.128). Pierre shares with them only the latter activity, not the intellectual greatness of Freud et al. His jealous jibe is provoked by his current recognition that he will never attain the heights of his intellectual ambitions. Moreover, his emotional solitude of temporary relationships, relieved by the substitute family he finds in his colleagues (p.118), is as great as Claude's.

The contrast between word and deed, between narrating and narrated worlds, is even greater in the case of Rémy's fictions of desire. Presenting himself as God's gift to women, as the super macho lover needing four women to keep him happy, 'a writer like Susan Sontag, an Olympic high jumper and a super bitch to liven up the group' (p.108) as well as his wife, Rémy's performance reveals him to be a child. We see him stumbling from the beds of Diane and Dominique in similar fashion, his round naked body tripping over things as they, in maternal fashion, call out to him telling him where to find his clothes, reminding him not to forget his watch and wedding ring (p. 106). Like Pierre, he is intellectually dominated by women, seduced, he claims, more by what is in Barbara Michalska's head - that 'superintelligence' - as she tells him about Laing's anti-psychiatry, than by 'large breasts or long legs' (p.41). While he seems like a mother's boy in his desire to have the same woman to come home to, this contrasts with his actual use of power politics to maintain his superiority. This is especially evident in his refusal to talk to Louise after the revelation of his infidelities when he imposes the power of veto by taking sleeping pills 
and drifting off into silence (p.157). As Dominique points out, sex for Rémy is a way of appropriating a woman's strength and of neutralizing her power (p. 148). As well, he is the most forthrightly misogynist of the four, initiating all the putdowns which trivialize the statements and activities of Diane and Dominique. While he has power, Rémy lacks awareness of others, as we see in the juxtaposed scenes where, adopting an easy sexist answer, he attributes Louise's bad temper to the onset of her period. The montage undercuts this by showing Louise's version of the day's events, revealing her infatuation for her tennis teacher. But Rémy can never know others, can never have a meaningful exchange, because he lacks self-awareness.

Through such traditional techniques of irony as juxtaposition of contrasting views and inversion of expected norms, Arcand develops his thesis about the lack of communication between men and women and the consequent emotional solitude of the individual, raising questions about current sex roles. At the heart of this problematizing of the norms of heterosexual intercourse is the gap between narrating and action. This relates to a broader theme of artifice and illusion. There are many bits of dialogue which would serve as examples - Pierre's statement, for instance, that he has only 'plastic eggs with hormones bought in the village' because he hasn't had time to buy any real eggs in the city (p.60) - where conventions of nature and culture are turned upside down. More central, however, is the gap between narrating and narrated worlds we have observed which is directly linked to the theme of lying foregrounded in the film through Rémy. Scene after scene dramatizes Rémy lying to his wife. At the breakfast table, he replies to her question that he is thinking about how happy they are together, while the stage directions tell us they smile tenderly: 'Il mentent tous les deux.' As Pierre says to him: 'you lie like you breathe.' Rémy himself says 'le mensonge est la base de la vie amoureuse, comme c'est le ciment de la vie sociale' (p.33). Certainly, it is the basis of his life. It is also the grounding of the film's life. Mario, the silent lover of Diane, points this up when he returns at dinner. After being party to the men's conversation in the afternoon, he is surprised finding a fish pie at the centre of their attention instead of an orgy underway (p.125). All the talk about sex is a substitute for sexual activity. The duplicitous nature of words are again the focal point of the second last scene. Gathered around the breakfast table after their 
night of 'truth,' the group are discussing the story of a colleague, Robert Turmel, and his relationship with an Italian woman. Each speaker has a different version of the affair and each holds it as truth told to them by either Robert or his wife. The web of facts grows increasingly dense as the group takes sides realizing, despite Pierre's denial that someone who knows him wouldn't lie to him and Diane's swearing that her version is the truth, that someone is lying. The episode acts as a mise en abyme of the film encapsulating the complex network of claim and counterclaim, of words and actions that establishes the textual irony. Pierre's words ending the debate resonate also throughout the film, pointing to the difficulty of ever knowing what any of the characters if really doing: 'Moi, $j$ 'ai l'impression qu' on ne saura jamais vraiment le fond de l' histoire' (p. 173). Although the 'histoire' that can never be affirmed as truth here translates as 'story,' in a film about historians history is never off stage.

That all characters are word beings each with their own story to tell and that history is a series of competing fictions are the 'truths' of relativity and negativity being acknowledged in the academy today. In The Decline of the American Empire, the recognition of the instability of the narrating instance, of the unreliability of words, serves to destabilize the precepts and roles on which the clichéd characters are modelled by inviting us to compare words and actions and to examine one character's version against another. Lying plays a critical function within the narrative: it is also a crucial element in the intertextual play of the film set within the texts of cinema and historiography. The two are interrelated. By exploring the former, we become aware of the degree to which Arcand's film comments on current developments in the writing of Quebec history. The Decline of the American Empire is a parody of the films of Eric Rohmer, the French cinéaste who has specialized in moral tales and proverbs that comment on contemporary social mores through a film technique which places soundtrack and visual image in counterpoint. Arcand has picked up Rohmer's ironic and comic style of making his characters say one thing while their body language shows them doing something else. But in Rohmer's films, especially in Ma nuit chez Maud which deals with desire and seduction, conversation is erotic. Arcand has burlesqued Rohmer: conversation is not the high seduction Rémy dreams of, instead it is about seduction. Talk has become banal and vulgar. As in Ma nuit chez 
Maud, this is the conversation of intellectuals. That their discussion and debate has become so trivialized is the point that Arcand is raising with respect to Quebec historiography, perceived to be in decline.

To elaborate on this point is to follow another intertextual network once again established by the silent Mario. The irony of having this anti-intellectual man of action ('quand a me fait bander (indiquant Diane), je la fourre. Je me pose pas de question.' p. 125) raise the intellectual issues of the film is an additional irony which ultimately compounds the point Arcand is making. Departing in the morning, Mario offers Diane a present in silence. It is a history book whose title the spectator briefly glimpses, Notre passé, présent, et nous by an author whose name is even more fleetingly on the screen: Michel Brunet. The title is inscribed in a long tradition of Quebec history writing which fosters Quebec identity through the enactment of the province's motto, 'Je me souviens.' Most clearly the title echoes Lionel Groulx' famous nationalist work, Notre mâttre, le passé where he writes about heroes like Jacques Cartier, Dollard des Ormeaux, Papineau and the period of the Rebellion of 1837, the latter essay ending with the words of Mgr. Bourget, Archbishop of Montreal,'parole d'une éloquence un peu dure peut-être, mais parole de grand évêque et profondément humaine. ${ }^{12}$ Eloquent, humane, moral - all the things that the historians of The Decline of the American Empire are not. For this we have their own words, or at least Rémy's words, qualified as they are by his unreliability, the opening words of the film which extol the importance of quantificative history, informing us that: ' 1 'histoire n'est pas une science morale. Le bon droit, la compassion, la justice sont des notions étrangères à l'histoire' (p.11).

It is precisely this shift from idealist mythmaking history in support of a Catholic nation to history as science that is the subject of Michel Brunet's collection of essays, Notre passé, le présent, et nous. The celebrated historian died not long before Arcand's film was made. Brunet is noted for having demystified Quebec historiography by showing how it had served a nationalist discourse grounded in the myths of clericalism, agriculturalism and the state. This collection of articles on a variety of subjects ranging from the North American adventure in the early days of the colony and the British conquest in the French North American adventure through to present day problems and Trudeau via a reflection on Quebec's situation as a colony and the familiar questions of clericalism and nationalism, includes 
several essays on the teaching of Quebec history currently in a state of crisis. Succinctly formulated in his preface, this crisis occasioned by the fact that since the research of specialists may no longer be embellished, many are no longer interested in Quebec history. ${ }^{13}$ As a result, young people know nothing of their history expect a few venerable clichés (p.117). This present scorn for history is no improvement over the spiritualist embellishment of history. In both cases, the past is avoided, a situation which for Brunet poses the most grave consequences because it paralyzes action for the future (p.13).

Quand une collectivité choisit d'ignorer son passé, c'est parce qu'elle refuse de faire face aux défis du présent et $n^{\prime}$ a pas l'audace de se bâtir un avenir. En effet, si quelqu'un est incapable de réunir les faits qui expliquent d'une façon cohérente son passé, comment peut-il comprendre son présent et connaître les données qui lui permettront de construire avec lucidité son lendemain? (p.11)

For Brunet, the importance of history and consequently the only way to approach its study in writing or teaching is to 'graspit in its relationship with the present' (p.117). Assuming Brunet's mantel in the name of a critical historiography, Denys Arcand sets out both to denounce the decline of Quebec history and the demise of its historians, who have buried history, and to carry out a tentative exploration of the past in its relation to the present.

Since the goal of such an enterprise is to change the future, at least as Brunet envisages the study of history, Louky Bersianik should find encouragement in the project. That she and others do not, however, raises questions about Arcand's rhetoric. The cynical, disabused tone of his depiction of the Quebec intelligentsia and the relations between the sexes which show the status quo turning around and around and down to death is accompanied by a fundamental anti-intellectualism, in which characters talking about a life of cries, grunts and touch, are unmasked by a character who lives a life of unreflective action. The fact that this anti-intellectualism and the limitations of current sex roles on human development and happiness are problematized, still leaves the spectator with the question: is this enough? Can one just raise questions about the stability of the fictions currently regulating our social and intellectual life? Is parodic deconstruction enough? It all depends on who is asking the question and on whose interests are 
being served by the fictions in question. For the power of cliché is such that, although recontextualized, convention exerts its power in any new context. It is difficult for the spectator to distinguish between cliché used straight, unself-reflexively and cliché used in a reflexive critique. Parody, another form of quotation, is considered to be 'authorized subversion, ${ }^{14}$ so easily is the work reappropriated. Parody is the coded form criticism takes in totalitarian societies because parody depends on the spectator sharing the historical horizon of interpretation with the writer in order to recognize the new parodic context. A technique deployed by the muffled in an ideological struggle, parody may be read as confirming the authority of the textual norm or as criticizing that norm depending on the knowledge and perspective one brings to the text. Bersianik's emotional reaction to Arcand's film reminds us that parody is not always enough. There are times and places when anger is necessary. To diffuse our anger by rendering a critique as parodic reworking of cliché may be to fall into the trap of passively maintaining the status quo.

This status quo, as feminists know too well, has a long way to go before the presence of the feminine will be acknowledged as a source of value. Our social fictions are the ideologies into which we are subjectively bound. The fictions of the status quo serve the interests of men. Although Arcand's film may trouble the stereotypes enough to invite a reflective man to begin a critique of patriarchy, it provides no feminist programme, ${ }^{15}$ constructs no subject position for the female spectator. As we have seen, at every step the possibility of seeing otherwise is raised through the textual irony, the meditation on lying and a few brief examples of a world in which women relate to other women. But this is not developed. Consequently, the subject position constructed by the film is one for the male gaze. To allow oneself to be interpellated into this gaze, to accept its view that the status quo continually reproduces itself, that change will never come about, is to be 'emasculated' ${ }^{16}$ and to reinforce a technicist and economic individualism. This is to ignore the enormous work of the last decade of the women's movement which, in Quebec, with the widespread acceptance of new diction bringing the feminine into the public realm (écrivaine), has been more popularly successful than in many countries. Bersianik shows us the way to become resisting spectators, to give voice to our anger. But emotional response is only the first step in creating a space for the feminist gaze. 


\section{Notes}

1 Louky Bersianik, 'L'Empire du statu quo,' Le Devoir, August 9, 1986, p. C1. Rpt. with translation, Tessera, No. 4, Contemporary Verse 2, 11, Nos. 1 \& 2 (Summer, 1988), 42-53.

2 Anne Legaré, 'A propos de quel déclin?' Le Devoir, 23 août, 1986, p. C2.

3 All texts which are rewriting, that is preeminently parodic or quoted texts, translations and critical texts, are considered to be texts in the second degree, or squared texts, by Gérard Genette, Palimpsestes, Paris: Seuil, 1982. His distinctions between text, story and discourse, as modified by Mieke Bal, are significant here. By story, I refer to the fable unfolding in chronological line, while the discourse is the organization of this narrative by a focalizer and narrator. The text is the total verbal structure located in its intertextual network, in its effects of irony and parody.

4 These are the terms of Benveniste for the double focus of the act of enunciation which encompasses both the utterance and the act of enunciation as reformulated by Gérard Genette in relation to the novel as mimesis and diegesis, the acted and the narrated levels of the text, or story and discourse.

5 Denys Arcand, Le déclin de l'empire américaine (Montréal: Boréal, 1986), p.12.

6 Barbara Johnston, The Critical Difference (Baltimore: John Hopkins, 1980).

7 Gilbert Guez, Le Figaro, quoted on back cover of script.

8 'Arcand m'a bien donné un contrat de recherche d'une semaine, en novembre 1984, dans le cadre de la pré-recherche d'un film devant alors porter sur les rapports hommes/femmes.' Louise Vandelac, 'Le déclin de l'empire américain,' Resources for Feminist Research 15, No. 4 (December 1986/ January 1987) p.60.

9 Louise Vandelac, pp. 59-60.

10 Andrea Dworkin, Intercourse (New York: Collier-Macmillan, 1987).

11 Luce Irigaray, This Sex Which is Not One. Trans. Carolyn Burke (Ithaca: Cornell, 1985), p. 172.

12 Lionel Groulx, Notre maître, le passé (Montréal: Librairie Granger, 1936), p. 131.

13 Michel Brunet, Notre passé, le présent, et nous (Montréal: Fides, 1976), p. 11.

14 Linda Hutcheon, A Theory of Parody (London: Methuen, 1984).

15 By feminist, I mean a critical emancipatory discourse for women, not another discourse on women.

16 Judith Fetterley, The Resisting Reader (Bloomington: University of Indiana Press, 1978). 